\title{
CAN LATIN AMERICAN PRODUCTION REGIMES COMPLEMENT UNIVERSALISTIC \\ WELFARE REGIMES? \\ Implications from the Costa Rican Case
}

\author{
Juliana Martínez Franzoni \\ University of Costa Rica \\ Diego Sánchez-Ancochea \\ University of Oxford
}

\begin{abstract}
Much of the literature on political economy expects complementarities between (universal) welfare regimes and production regimes. This article draws from Costa Rica's showcase of human development and universalistic social policies to address how the production regime supports and constrains the welfare regime. We show that there were some positive relations between the two regimes at various points but that they were neither fully nor mostly complementary. At the heart of our interpretation of Costa Rica's performance - and Latin America's pervasive lack of complementarities-lies the dominance of structural heterogeneity in the production regime. Our analysis has significant implications for current theoretical and policy debates in Costa Rica and elsewhere. At the theoretical level, we highlight key features of production in Latin America and the need to consider such material bases as part of robust welfare policies. At the policy level, our argument stresses the importance of promoting both leading and lowproductivity sectors simultaneously and of securing stable funding mechanisms for the welfare regime. Our article thus offers a cautionary note to Latin American countries slowly moving toward the creation or re-creation of universal social programs in the context of relatively unchanged production regimes. Since tensions between production and welfare regimes may also be appearing in a growing number of postindustrialized developed countries, theoretical and policy implications can easily travel beyond Latin America.
\end{abstract}

Much of the political economy literature on developed countries assumes that national economic institutions build positive and lasting relations with social arrangements. Complementarities between the production and welfare regimes are not only expected but also considered a necessary condition for simultaneously achieving economic growth and equitable income distribution. In particular, universal social policies are expected to go hand in hand with production regimes that can effectively use skilled workers, improve productivity, and secure stable funding.

We thank Evelyne Huber, Maxine Molyneux, Jorge Rovira, Andrew Schrank, Ken Shadlen, Jorge Vargas Cullell, and three anonymous LARR reviewers for their substantive contributions, and the British Academy for two small grants supporting our larger research project on the formation of universal social policies in peripheral countries.

Latin American Research Review, Vol. 48, No. 2. (c) 2013 by the Latin American Studies Association. 
Although research on links between the production and welfare regimes in the periphery is scarce, recent publications stress the importance of stable complementarities between the two. Notably, Sandbrook and colleagues' (2007) pathbreaking analysis of social-democratic peripheral countries claims that the few countries successful in creating universal social policies also had supportive production systems making it possible.

Is this really the case? Must we expect stable complementarities between universal welfare and production regimes? And in the specific case of Latin America, does the recent move toward universalistic social policies require a simultaneous shift in the production regime to secure long-term sustainability?

This article explores these questions through a case study of Costa Rica as one of the few showcases of human development and universal social policies among peripheral countries in the past six decades. ${ }^{1}$ Costa Rica is one of the four cases examined in Sandbrook and colleagues' (2007) study of social democracy. In their view, Costa Rica's success during its golden age (1950-1980) resulted from the simultaneous role of universal social policies and an activist state in production matters. In the past three decades the country has faced growing pressures to adopt market-friendly policies but has succeeded in securing "the survival of a reinvented welfare state," thanks in part to "new earnings from tourism, financial services, textiles, high-technology, and nontraditional agricultural exports [that] have generated employment and important streams of revenue for the government" (Sandbrook et al. 2007, 94-95).

In this article we build on Sandbrook and colleagues' (2007) interpretation but develop a more critical and systematic approach to Costa Rica's trajectory. We argue that the relationship between production and welfare regimes has been inherently conflictive and subject to change over time. Although between 1950 and 1980 the country did succeed in creating better jobs and effectively funding its welfare regime, it also failed to upgrade its comparative advantages. Since 1980, Costa Rica has managed to develop new leading sectors, but with an increasingly informal and dual labor market allowing new tensions to emerge. Growing heterogeneity in the production regime is thus slowly leading to an increasingly segmented (and thus less universal) social policy. Changing the tax system would go a long way toward reducing problems in the welfare regime; we show how this has been politically impossible.

Through the Costa Rican case, we offer a systematic approach to the study of the relations between production and (universal) welfare regimes and reveal the complex and changing intermingling of both regimes in the periphery. Our analysis has significant theoretical and policy implications in the post-retrenchment, post-Washington Consensus era. At the theoretical level, we highlight key features of production in Latin America as well as the need to consider such material bases as part of robust welfare policies. We also argue that creating much-needed complementarities may be particularly difficult in the context of a globalized economy. At the policy level, our argument stresses the importance of promoting 
both leading and low-productivity sectors and of securing stable funding mechanisms through taxes for the welfare regime.

Below we summarize the literature on these relations, mostly drawn from research on postindustrial developed countries. We pay particular attention to research on universal welfare regimes and review the few available studies about the periphery. Second, we present an empirical analysis of what is usually considered the "Golden Age" (1950-1980) of expansionary, universal, and generous social policy in Costa Rica, followed by a period of remarkable resilience since the 1980s. We conclude by pointing out the conceptual and policy implications of our empirical findings.

\section{COMPLEMENTARITIES BETWEEN PRODUCTION AND (UNIVERSAL) WELFARE REGIMES}

Definitions of production and welfare regimes are highly contested (Coates 2005). Most observers agree, however, that welfare regimes refer to how people prevent and cope with social risks, whether individually or collectively, with a larger or lesser role for markets, states, and families (Esping-Andersen 1990). Production regimes, in contrast, refer to how economic agents, particularly the state and domestic and foreign firms, shape the quantity and quality of jobs created (Huber and Stephens 2001).

The debate about what this means and how to define complementarities between both regimes has been equally contested (e.g., Crouch et al. 2005). In this article, the term complementarities refers to welfare and production regimes reinforcing each other and securing mutual stability over time. Such complementarities between the regimes depend on two factors: the ability of the welfare regime to generate skills demanded by the production regime, and the existence of stable mechanisms (i.e., various types of taxes) through which the production regime secures resources to fund social policies. Although these two channels are intertwined (i.e., higher skills may lead to higher productivity and thus more potential funding), it makes analytical sense to discuss each separately.

The literature on welfare regimes, led by Esping-Andersen's $(1990,1996)$ pathbreaking contributions, studies the redistributive capacity of different welfare systems and identifies the labor market as the arena in which complementarities emerged. Based on constellations of social policies, markets, and families, welfare regimes involve different degrees of (de)commodification of social risks and different levels of income redistribution. Among OECD countries, EspingAndersen (1990) identified three welfare regimes-liberal, corporative, and social democratic-which depend on whether decommodification reached only people in need, specific types of workers, or everybody, as seen in the United States, Germany, and Sweden, respectively. Countries with universal social programs (including child care) and high decommodification of the workforce make it easier for women to join the labor force, rely on full employment for funding, and show a larger proportion of public servants. Welfare regimes shape labor markets as much as labor markets shape welfare regimes (Esping-Andersen 1990).

It is through labor markets that welfare regimes influence wage determination and productive strategies. Although Esping-Andersen does not explore this 
matter closely, Huber and Stephens (2001) offer some clues. Welfare states, they argue, are embedded in production regimes, understood as "patterns of relations between enterprises, financial institutions, labor and the government, and specific constellations of labor market and economic policies" (Huber and Stephens 2001, 23).

Huber and Stephens (2001), and others working within the same approach, expect that a certain functional relation exists between production and redistribution. For instance, liberal market economies tend to have limited tax revenues and targeted social policies (see also Perraton and Clift 2004). Although deep changes can take place in economic and social policies (Pontusson 2005) and "incoherencies" between them arise, there is some expectation that they will reinforce each other in the long run.

The literature on varieties of capitalism adopts a stronger notion of complementarities and posits that welfare regimes are shaped by the preferences and behavior of firms. In coordinated market economies (CMEs) — which have generous welfare states often revolving around universal principles-firms specialize in sectors like automobiles or machinery production, which demand workers with highly specific, not-easily-portable skills (Hall and Soskice 2001). Social and labor policies, particularly training, social security, and insurance for the unemployed, create incentives for this type of investment in nontransferable skills, thereby supporting the competitive strategies of firms (Estévez-Abe, Iversen, and Soskice 2001). Thus, social programs do not just involve costs for companies but also complement their productive specialization. At the same time, higher social spending contributes to higher income redistribution and gives rise to some of the most equal societies in the world.

In this view, incoherencies among social and economic factors may take place in the short run but will necessarily give way to complementarities between the production and welfare regimes: "Production regimes are conceptualized as institutional complementarities that reinforce one another. . . [T] gime can also be understood as a complement in the national production system" (Estévez-Abe, Iversen, and Soskice 2001, 146). In turn, complementarities lead to positive outcomes: business endorses specific types of social policy, and social policy helps increase business productivity in key sectors. ${ }^{2}$

The study of the complementarities between welfare and production regimes in the Nordic countries is particularly relevant for our study given the universal nature of their welfare regimes. Low inequality and high social spending went hand in hand with successful export performance and dynamic technological upgrading. Close collaboration between governments and firms contributed to the rapid expansion of new manufacturing activities and productivity in agriculture (Blomström and Meller 1991). Full employment was the norm, and informality was quite limited. As a result, the production system generated enough resources to fund universal social policies, which in turn contributed to further accumulation

2. Synergies between varieties of capitalism and welfare regimes arise from a common structure of incentives and set of institutions. Nevertheless, this perspective pays insufficient attention to conflict behind the creation and perpetuation of policies and institutions (see Pontusson 2005). 


\section{Latin American Research Review}

of human capital (Kokko 2010). Despite the pressures of globalization, most of the literature suggests that the complementarities between production and universal welfare regimes in the Nordic countries have remained stable over time (Kangas and Palme 2005; Pontusson 2011).

Two important features of the literature on OECD countries are thus worth highlighting. First, universal social policies are likely to be supported by the production regime. In particular, there is a presumption that the state will be able to create adequate funding mechanisms for policies a majority of actors endorse. Second, complementarities reduce the likelihood of sharp institutional changes - a point particularly emphasized by proponents of the varieties of capitalism approach.

Recent literature on Latin America and other countries in the periphery explores the links between production and welfare regimes. Some of this work also takes for granted the existence of stable complementarities. In particular, Ben Schneider's (2009) pioneering work highlights how the hierarchical nature of production in Latin America results in poor welfare efforts that over time reinforce negative rather than positive complementarities. Large business groups demand state support but have no need for and thus refuse to support the systematic improvement of human capital (Schneider 2009; Schneider and Soskice 2009). In turn, state policy inhibits technological innovation and the promotion of hightech sectors (Soskice and Schneider 2009). Negative complementarities are thus reflected in a production regime that over the long run perpetuates low skills, lack of technological innovation, and deep-seated inequality.

Other valuable studies pay more attention to the instability of Latin American institutions and policies_-and thus the lack of stable complementarities-but do not offer a systematic and consistent approach to relations between production and welfare regimes. In their study of social policy in three regions of the periphery, for example, Haggard and Kaufman (2008) highlight the influence of development patterns in the emergence of welfare regimes. Asian export promotion demanded the development of human capital and cost containment policies. In Latin America, however, import substitution enabled urban workers to access robust social services without harming profits by the business sector. Yet when Haggard and Kaufman explain the most recent changes, they focus on democracy and liberalization, leaving aside the production regime. They fail to offer a model of interrelations or a discussion of whether complementarities will survive. ${ }^{3} \mathrm{Hu}-$ ber's (2001) edited book addressed production and social policies in Latin America under capitalist relations while acknowledging changes over time. Yet contributors to the volume go back and forth between conceiving models as institutions or as a constellation of public policies. Interrelationships among trade, industrial, and social policies are not sufficiently addressed. ${ }^{4}$

3. Mares and Carnes (2009) also criticize Haggard and Kaufman (2008) for their use of ad hoc variables across time periods.

4. The application of the literature on welfare regimes to Latin America is innovative (see Filgueira 1998; Martínez Franzoni 2008c). Nevertheless, this research has paid limited attention to the links between the welfare regimes and production regimes analyzed. 
More relevant for our study of universalism in welfare regimes is the aforementioned book published by Sandbrook and colleagues (2007). In their exploration of the few successful cases of universalism on the periphery, they find stable complementarities between production and welfare regimes. In their view, "classical social-democratic regimes ... equate equity with a universal and comprehensive welfare state and a proactive state that creates good jobs with good wages" (Sandbrook et al. 2007, 27). Although these scholars are certainly aware of the tensions and constraints that globalization creates on both welfare and production regimes, they suggest that social democratic countries are able to maintain stable complementarities.

Our analysis of Costa Rica aims to nourish two primary debates: first, on complementarities in Latin America, and second, on the prospects for universal welfare regimes on the periphery. We make two arguments that contribute to a better understanding of the complementarities between regimes. First, we highlight the importance of specific funding mechanisms to secure the creation and expansion of welfare policies. Tax systems that are useful at one time may, however, become unsuitable later. Second, we warn against generalizations regarding the existence of stable complementarities-either positive or negative-in Latin America. We show how the nature of production and welfare regimes has changed significantly over time, affecting the interrelation between the two. As a result, we avoid static definitions of complementarities-dominant in some literature on postindustrial developed countries-and adopt a more dynamic framework. This endeavor improves our understanding of Latin America but also helps develop a richer interpretation of the future trajectory of many developed countries. France and Germany, for example, may be experiencing more changes in their production regimes than appear at first sight, with a notable impact on welfare provision (Palier and Thelen 2010).

\section{THE GOLDEN AGE IN COSTA RICA, 1950-1980: LINKS BUT NO REAL COMPLEMENTARITIES}

Drawing from foundations established in the early 1940s, between 1950 and 1980 Costa Rica developed a generous welfare regime based on universal principles. Expansion of social policies took place across sectors, from education and training to social insurance and social assistance. The production regime contributed by generating resources and a relatively effective funding mechanism. Rapid accumulation of capital, public incentives to reduce structural heterogeneity and overall state expansion contributed to the growth of well-paid jobs. Since payroll taxes and not general revenues were the main funding source for both social insurance and social assistance-the latter a rather unique feature of Costa Rica's trajectory-this expansion of formal jobs was particularly welcomed.

While the financial base of the Costa Rican welfare regime was more solid than that of other Latin American countries, other linkages between regimes were not so successful. The production regime did not fully complement the development of the universal welfare regime; it faced enormous shortcomings in transforming newly available human capital into economic upgrading. In fact, Costa Rica's comparative advantages continued to revolve around coffee and bananas-two 
sectors that do not require significant amounts of skilled labor and cannot generate sustained productivity increases.

\section{THE WELFARE REGIME: A RAPID AND BOTTOM-UP EXPANSION OF UNIVERSAL POLICY}

Across the period 1950-1980, Costa Rica transformed its welfare regime more radically and more successfully than any other country in Latin America. Costa Rica moved from a relatively traditional liberal, familistic system to one centered on state social intervention. Unlike other countries, Costa Rica's new arrangements had increasing benefits based on universal principles.

The rapid expansion of total social spending provides clear evidence of Costa Rica's new statist welfare regime. Between 1958 and 1980, social spending as a percentage of gross domestic product (GDP) increased from 7 percent to 14.9 percent, with particular growth in health, education, and social assistance. This contrasts sharply with the performance in neighboring countries. During the entire period, in the Dominican Republic and El Salvador, for example, social spending as percentage of GDP remained below 5 percent.

The expansion of public social spending is clearly illustrated by health care and pensions, two of the most important social sectors. Health-care insurance, disability, and old-age insurance were established in 1941, before the country's civil war, under the Social Insurance Fund (Caja Costarricense de Seguro Social, or CCSS). Far from creating distinct benefits according to occupations, as in the Southern Cone, the CCSS aimed at a gradual outreach to the workforce first and later to the entire population with the same set of benefits. Moreover, rather than increasing coverage from the middle- and upper-income groups down, social insurance expanded from the lower-income groups up. Additionally, insurance was expanded to include dependent families (spouses in 1954 and children in 1965) in all available health-care services (Martínez Franzoni and Mesa-Lago 2003).

From 1950 onward, social insurance expanded, at first slowly and then rapidly. In 1961, legislation mandated universal access to health care by 1971. In 1970, wage ceilings were removed, making health-care insurance mandatory for all workers, including those with the highest income. In 1971 the same occurred with old-age and disability insurance. Pension insurance became mandatory and the quota of the state diminished in exchange for an increase in employer quotas, which would attenuate the endemic state debt. In 1973 and 1974, a noncontributory regime was established for poor people to access health-care and old-age pensions. In 1975 a voluntary program also reached the self-employed. Between 1970 and 1980 contributory coverage went from 39 percent to 68 percent (Rosenberg 1983), while direct health-care insurance reached almost 70 percent of the economically active population (EAP) and pension insurance reached almost 50 percent.

During the 1970s, two institutions targeting the poor complemented the rapid expansion of universal services. These were the Mixed Institute of Social Assistance (Instituto Mixto de Ayuda Social, IMAS) in 1971 and the Family Allowance Fund (Fondo de Desarrollo Social y Asignaciones Familiares, FODESAF) in 1974. During its first year of operation, FODESAF was receiving 1.1 percent of GDP 
(Trejos, cited in Rovira 1987); since 1975 it has regularly funded more than twenty institutional and fifty social programs (Montiel 2001).

Between 1971 and 1973, the first national plan for public education drew on planning tools promoted by the Alliance for Progress. In addition, a constitutional reform made basic education mandatory, including the first three years of secondary school, whereas preschool and secondary education continued to be state funded. By 1980, school coverage was 90 percent at the primary level and 40 percent at the secondary level. Starting in 1965, technical training also expanded, with the creation of the National Institute of Learning (Instituto Nacional de Aprendizaje, INA).

As a result, right before the economic crisis of 1982, the Costa Rican welfare regime was the most universal and the least stratified of Latin America (Filgueira 1998). State intervention rested on the combination of (a unified) social insurance with social assistance programs, all heavily funded by payroll taxes.

\section{THE COMPLEX LINKS WITH THE PRODUCTION REGIME}

Costa Rica's production regime succeeded in generating the revenues required to complement the expansion of social policy. Public employment and incentives supporting small and medium firms, especially cooperatives, succeeded in creating a growing number of well-paid jobs. Through payroll taxes, these jobs generated sufficient financial resources to support generous social policies.

The state relied on several instruments to play an active role in the creation of an economy with a growing formal sector. Public investment was high throughout the period but increased particularly fast during the 1970s (table 1). The share of public investment increased from 21 percent in 1960 and 23 percent in 1970 to almost 40 percent in 1980. Public investment was one of the key factors behind the rapid expansion of real gross capital accumulation, which increased by an annual average of 8.2 percent between 1951 and 1980 and contributed to a rapid expansion of the economy.

In addition to its direct economic participation, the state influenced capital accumulation through more indirect channels. In 1949 banking nationalization turned the state into a major player in the determination of national investment. Public banks pursued a double objective: the promotion of leading sectors and the creation of new firms, particularly in manufacturing. Successive administrations also influenced the direction of production through expanding subsidies and protecting the domestic market.

Many of these incentives initially targeted coffee. By 1957, more than one-third of all credit was still going to the agricultural sector and half that to coffee producers, who also had public support to purchase fertilizers, introduce new plants, and develop new growing techniques (Rovira 2000). As a result, during the 1950s the volume of coffee production grew by an annual average of 9 percent, three times faster than in the previous decade. Gradually, however, new incentives were created to promote manufacturing. The Industrial Protection Law, passed in 1959, established several incentives-including a 300 percent tariff increase on imports 
Table 1 Some economic indicators for Costa Rica, 1960-1980

\begin{tabular}{llllll}
\hline & 1960 & 1965 & 1970 & 1975 & 1980 \\
\hline GDP per capita (colones 1966) & 2,582 & 2,624 & 3,162 & 3,748 & 4,238 \\
Average growth $^{\mathrm{a}}$ & & 0.32 & 3.81 & 3.46 & 2.49 \\
GDP per capita (2,000 US\$) & 1,798 & 1,946 & 2,372 & 2,825 & 3,189 \\
Investment/GDPb $^{\text {(\%) }}$ & 16 & 19 & 20 & 22 & 24 \\
Public investment/total $^{\mathrm{b}}(\%)$ & 21 & 31 & 23 & 32 & 39
\end{tabular}

Source: Vargas (1998) and World Bank's World Development Indicators.

${ }^{a}$ Annual average rate in the previous five years.

bBoth variables were measured in current colones.

competing with domestic production, and a 99 percent exemption on import duties required for domestic manufacturing (e.g., machinery, motors, raw materials, intermediate inputs). Costa Rica's entry into the Central American Common Market in 1963 created additional incentives for manufacturing firms.

What made Costa Rica unique when compared to neighboring countries was the spread of small producers both in agriculture and in industry, and their cohabitation with larger firms. Particularly important was the expansion of cooperatives, actively promoted by the state. Between 1959 and 1963, co-ops rose from 42 to 218 . By 1985 there were 464 co-ops, accounting for 11 percent of total GDP and 15 percent of total exports (Reding 1986). Cooperatives were particularly important in the coffee and dairy sectors. The Federation of Coffee Cooperatives was created in 1962 and was immediately supported by public banks. By 1985, the federation's thirty-three affiliates sold 40 percent of their harvest directly to the world markets (Brenes 1990). Meanwhile, the Cooperativa Dos Pinos, producing milk and other daily products since 1947, grew rapidly to become one of the most important firms in the country (Meléndez 1998).

The state also played a prominent role as employer, largely a result of growing social services. Between 1950 and 1980, public employment increased at an average annual rate of 7.3 percent, going from 6.2 percent to 18.5 percent of the EAP (Castro 1995). The expansion in the number of doctors, teachers, nurses, and other public personnel was extraordinary-doctors alone increased from 3.1 to 7.8 per every 1,000 people (Trejos, cited in Martínez Franzoni 2008a). The continuous expansion of social security insurance also reflects a sustained formalization and, therefore, improved quality of labor.

During the 1970s, unemployment remained low (5 percent), and informal jobs accounted for only 14 percent of the nonagricultural EAP (Villasuso 2008). Real wages systematically grew-for example, between 1950 and 1979 the minimum wage increased at an annual average rate of 1.9 percent (Sánchez-Ancochea 2004) — without necessarily affecting business profits.

The expansion of formal employment was particularly important because social policy was largely funded by payroll taxes, paid only by formal workers, mostly salaried. This was, of course, not unique to Costa Rica, since almost all Latin American countries followed the continental model of social insurance. Yet 


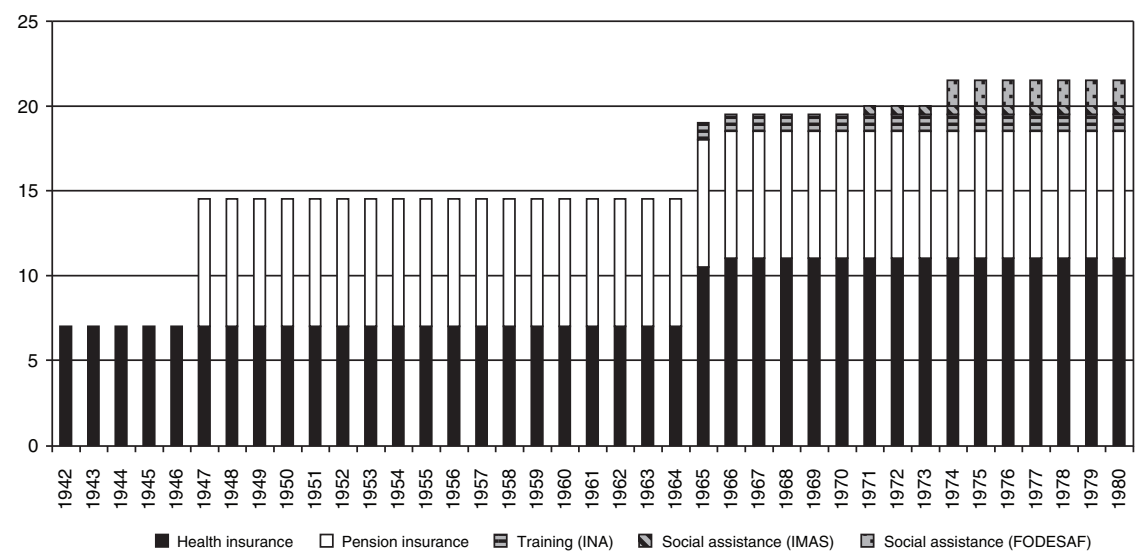

Figure 1 Overall rates in payroll taxes, 1942-1980. Data from Caja Costarricense del Seguro Social and Sistema Costarricense de Información Jurídica.

Costa Rica was special in at least two ways: (1) the growing reliance of welfare funding on payroll taxes, and (2) payroll taxes becoming a funding source for noninsurance components of social policy, including social assistance and training. Figure 1 shows the evolution of payroll tax rates from the creation of social security in 1941 until 1980. After almost two decades of stability, payroll tax rates increased rapidly after 1965 to fund new social programs, including the INA, a targeted program for the nonworking poor (IMAS), and a large social development fund (FODESAF).

Payroll taxes in Costa Rica thus became a relatively effective mechanism to solve political constraints in the expansion of taxation facing all Latin American countries during the period. Expanding a tax that had existed since the early 1940s and was easy to collect was more politically attractive to decision makers than creating a truly progressive and effective income tax or new, indirect taxes from scratch. ${ }^{5}$ In fact, Costa Rica was not particularly successful at raising nonpayroll taxes: in 1970, for example, its tax burden was just 12 percent of GDP, compared to almost 15 percent in the Dominican Republic (Sánchez-Ancochea 2004), a country with much lower public and social spending. Some segments of the business elite, especially those competing in regional markets, did complain about the payroll tax hikes of the early 1970s. Most, however, benefitted from high levels of protection. Formal workers faced a high tax burden yet were also experiencing growing real wages and sound social services.

The production regime thus made a more positive contribution to the welfare regime than in many other Latin American countries. Formal employment was the norm; the middle class broadened; and low-productivity activities-particularly in the agricultural sector-received more support than in the rest of Central America,

5. After several years of negotiation with the business sector, in 1967 government finally introduced a sales tax of only 5 percent, which included several exceptions. 


\section{Latin American Research Review}

the Andean countries, and even larger countries like Brazil. This contributed to the expanded payroll tax, which gave social insurance and, more surprisingly, social assistance a stable funding mechanism mostly lacking elsewhere.

Despite these achievements in terms of funding, however, Costa Rica failed to establish other key components of complementarities between production and welfare regimes: economic upgrading was limited, and state dependence was excessive. When the creation of jobs in the private sector slowed down during the 1970s, the government responded with new state-owned firms, more social programs, and a larger share of public employment, leading to an open and bitter conflict with private businesses (Güendell 1988).

More important, unlike countries like Singapore or Taiwan, and previously, Finland or Sweden, Costa Rica failed to transform human capital into external competitiveness and new exports with higher technological content. In 1982, coffee and bananas still made up 56 percent of all exports, and Costa Rica remained a primary-product exporter. The inability to diversify exports along with the rapid increase of imports led to a growing current account deficit: from US\$74 million in 1970 to US\$664 million in 1980, despite the growing international prices of coffee and other exports. More people were accumulating human capital (through investment in education but also from receiving improved and extended health care), but the production system was unable to draw on them effectively to reduce external dependence.

\section{A NEW TYPE OF PROBLEM: THE UNCERTAIN COSTA RICA, 1980-2010}

The contradictions between the production and welfare regimes-and within the production regime itself-became evident at the beginning of the 1980s. Costa Rica's dependence on primary exports complicated the country's capacity to successfully cope with deteriorating global conditions. In less than two years (from August 1980 to May 1982), the colón suffered a sharp devaluation of more than 600 percent, and short-term foreign debt grew rapidly (Villasuso 2008). Between 1981 and 1982, real GDP decreased more than 10 percent.

Costa Rica responded to the crisis by transforming its production regime around the development of skill-intensive comparative advantages. Through generous tax incentives and subsidies, new sectors were expected to attract human capital and expand productivity, thus supporting the resilient welfare regime. Contrary to other countries in Latin America that were aggressively moving toward neoliberalism, Costa Rica sought to pursue the type of "high road" to development called for by Korzeniewicz and Smith (2000). ${ }^{6}$

In this section we show that the results have been less encouraging than initially expected. New comparative advantages were indeed created, but the new production regime deepened structural heterogeneity-widening the productivity gap between high- and low-productivity sectors-and contributed to the

6. For Korzeniewicz and Smith, the "high road" toward development involves (1) high economic growth supported by rapid expansion of labor productivity, (2) more equitable income distribution, and (3) a deepening of formal democracy and more participatory state-society relations. 
expansion of informality. This generated new tensions between the welfare and production regimes. The welfare regime, which is still largely reliant on payroll taxes, has faced increasing funding difficulties. Growing labor-market segmentation has additionally contributed to a parallel segmentation in the welfare regime-with high-income groups exiting the public system. Finally, social policies failed to provide the skills badly needed by new economic sectors. Finding solutions to some of these problems (through changes, for example, in the tax system) has proved politically and economically difficult.

\section{The Transformation of the Production Regime}

Since the mid-1980s, the Costa Rican production regime was transformed with the aim of upgrading the leading sectors of the economy. The Figueres administration (1994-1998) spelled out Costa Rica's strategy better than any other administration. The Figueres government aimed to develop "an aggressive policy of investment attraction" in sectors that made "a sophisticated and well-paid use of productive resources and not extensive and poorly rewarded use of cheap labor" (Ministerio de Planificación Nacional y Política Económica 1998, 51).

The promotion of foreign investment in high-tech manufactures, back offices, and other services-partly through tax subsidies-was particularly important. Companies like Intel, Procter and Gamble, and Abbot invested in the country and contributed to an expansion of exports and skilled employment. Between 1996 and 2007, exports grew at an annual average rate of 8.6 percent-surpassing US\$9.3 billion in 2007. As a result of this sustained expansion, Costa Rica has become one of the best export performers in Latin America: in 2007 it was ranked fifth in terms of exports per capita after Chile, Panama, Mexico, and Venezuela (all of which benefited from high commodity prices or a large re-export level) (figure 2). Costa Rica's exports also enjoy a higher technological content than the Latin American average (excluding Mexico): as table 2 indicates, in 2005 hightechnology exports accounted for 29 percent of all exported goods from Costa Rica, as compared to only 4 percent in the whole region, excluding Mexico.

At the same time, the state incrementally withdrew from other productive functions that would enhance competitiveness and expand productivity. First, financial liberalization, which started in the mid-1980s, reduced public influence in the allocation of investment and its overall capacity to support small and medium firms. Increasing competition from private (mostly foreign) banks has also led public banks to abandon development banking and concentrate on expanding profits and competitiveness.

Second, state capacity to promote specific sectors and support operations among small and medium firms has diminished. The state can no longer protect specific sectors through high tariffs because of international commitments under the World Trade Organization and a growing number of free trade agreements. According to Vargas Cullel $(2008,17)$, the Costa Rican state has also witnessed a "weakening of the institutions in charge of promoting and supporting traditional productive sectors in manufacturing and agriculture." Between 1990 and 1993, for example, the budget of the National Production Council—in charge of 
160 Latin American Research Review

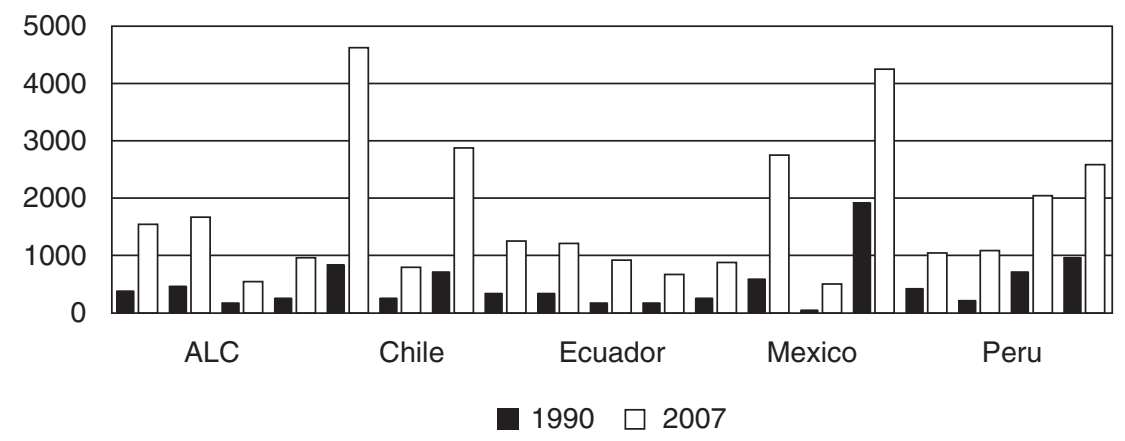

Figure 2 Latin America exports per capita in US dollars, 2000 and 2007. Author's calculations with data from the World Bank World Development Indicators database, at http://databank.worldbank.org/ddp/home.do?Step $=12 \mathcal{E} i d=4 \mathcal{E} C N O=2$.

Table 2 Costa Rica and Latin America (without Mexico): Export structure by technological content, percentage of total exports, 1987-2005

\begin{tabular}{|c|c|c|c|c|c|c|c|c|c|c|}
\hline & \multicolumn{2}{|c|}{1987} & \multicolumn{2}{|c|}{1990} & \multicolumn{2}{|c|}{1995} & \multicolumn{2}{|c|}{2000} & \multicolumn{2}{|c|}{2005} \\
\hline & CR & LA & $\mathrm{CR}$ & LA & CR & LA & $\mathrm{CR}$ & LA & CR & LA \\
\hline Primary goods & 68.4 & 46.3 & 57.6 & 49.8 & 58.3 & 40.2 & 25.9 & 41.1 & 23 & 47.4 \\
\hline $\begin{array}{l}\text { Manufacturing based } \\
\text { on natural resources }\end{array}$ & 8.7 & 27.0 & 11.4 & 24.5 & 15.7 & 28.6 & 13.7 & 27.6 & 14 & 22.9 \\
\hline $\begin{array}{l}\text { Manufacturing low } \\
\text { technology }\end{array}$ & 12.1 & 10.6 & 12.8 & 10.3 & 10.9 & 9.0 & 16.8 & 8.6 & 14.4 & 7.5 \\
\hline $\begin{array}{l}\text { Manufacturing medium } \\
\text { technology }\end{array}$ & 5.2 & 12.7 & 6.1 & 12.2 & 7.0 & 13.8 & 16.6 & 14.0 & 18.7 & 15.8 \\
\hline $\begin{array}{l}\text { Manufacturing high } \\
\text { technology }\end{array}$ & 3.2 & 2.2 & 3.2 & 2.0 & 2.9 & 5.7 & 26.6 & 6.0 & 29 & 4.1 \\
\hline Other transactions & 2.4 & 1.2 & 9.0 & 1.3 & 5.3 & 2.7 & 0.5 & 2.7 & 0.8 & 2.3 \\
\hline
\end{tabular}

price controls and the promotion of domestic agriculture-decreased by twothirds.

These reforms contributed to the desired expansion of some new highproductivity sectors but, unfortunately, also resulted in growing structural heterogeneity. In many ways, two different countries are currently being laid out: one based on nontraditional manufacturing exports and modern services (mostly relating to tourism and finance) and the other based on more traditional activities (like other manufacturing and many other services) barely able to increase productivity for successful competition with imports. Leonardo Garnier, minister of education since 2006 under the Arias and Chinchilla administrations, and Laura Blanco describe it well in a recently published book: "On the one hand, new activities —-mainly linked to exports, tourism and certain services—emerged 
that are characterized by high productivity, a more skilled labor force and that, as a result, pay higher and growing wages. ... On the other hand, the growth of other types of jobs characterized by low productivity, low skills and low income, is worrying" (Garnier and Blanco 2010, 284, our translation). In the case of the manufacturing sector, for example, productivity in the export-processing zones, where most high-tech activities are concentrated, was 7.5 times higher in 2005 than in 1991, while it remained almost stagnant in the rest of the manufacturing sector.

A major shortcoming of some of the most dynamic sectors, including high-tech manufacturers and many tourist establishments, is that they are delinked from the rest of the economy and have few positive effects on productivity and wages at the macro level (Ernst and Sánchez-Ancochea 2008; Paus 2005). Transnational corporations (TNCs) have little interest in creating new supply chains with domestic firms, and as a result, their aggregate impact is relatively small. Small and medium Costa Rican companies are generally incapable of providing the type of inputs that TNCs demand (Paus 2005) because they lack financial and technological support to accumulate knowledge-based assets.

\section{The Universal Welfare Regime's Formal Resilience}

The welfare regime has apparently shown remarkable resilience in the face of the changes in the production regime and the global policy environment. Contrary to expectations of neoliberal economists and the experience of other Latin American countries, Costa Rican governments did not introduce major changes in the system. In terms of the guiding principles behind the welfare regime, universal access to social policy remained, as did equity and solidarity. This means that Costa Ricans continue to be entitled to access universal public services such as health care and education regardless of income and contributions. Health-care benefits under social assistance are the same as those under social insurance. Dependent family members continue to have access to similar services, as do directly insured workers.

In terms of public social spending, the economic crisis of the 1980s certainly had a harsh yet not necessarily lasting impact (Segura-Ubiergo 2009). Spending started recovering quickly and sustainably, almost regaining the levels preceding the economic crises (see figure 3). Similar to Chile and only lower than Argentina, Costa Rica currently spends about $\$ 800$ per person each year in real terms.

Across policy sectors, the coverage of public social services has continued to increase. In education, part-time preschool (age five) reaches more than 90 percent of girls and boys, and primary education reaches universal coverage (see figure 4). Although both levels are part-time, they at least partially facilitate laborforce participation.

In health care, since early 2000 when databases became more reliable than before, coverage has showed a positive trend, particularly among the self-employed. Currently, social insurance reaches 60 percent of the EAP (almost 70 percent of salaried workers and about 35 percent of the self-employed), in addition to family dependents and the poor (see figure 5). Altogether, various eligibility criteria 


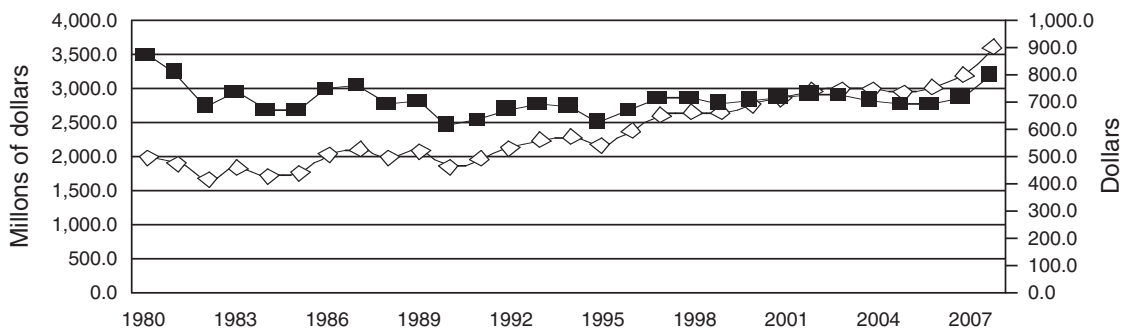

Figure 3 Costa Rican social spending, total (left axis) and per capita (right axis), 1980-2008. Data from Autoridad Presupuestaria, Ministry of Finance.

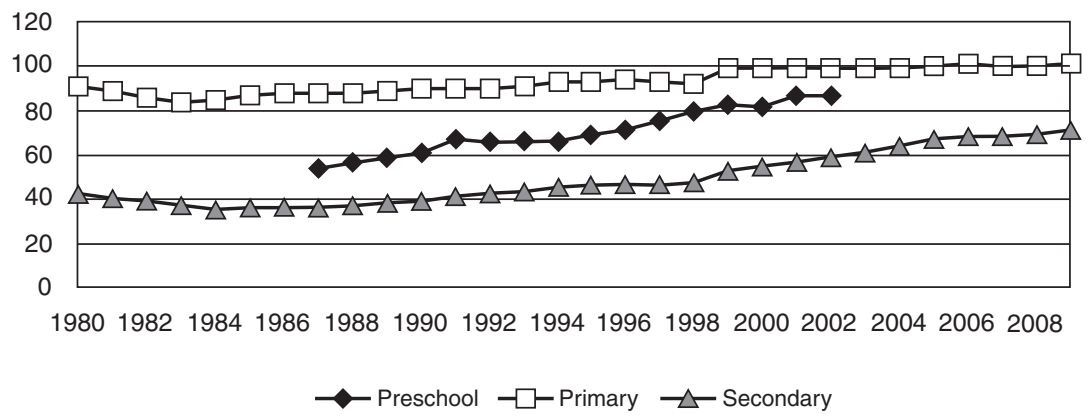

Figure 4 Costa Rica, net school enrollment by level, 1980-2009 (percentages).

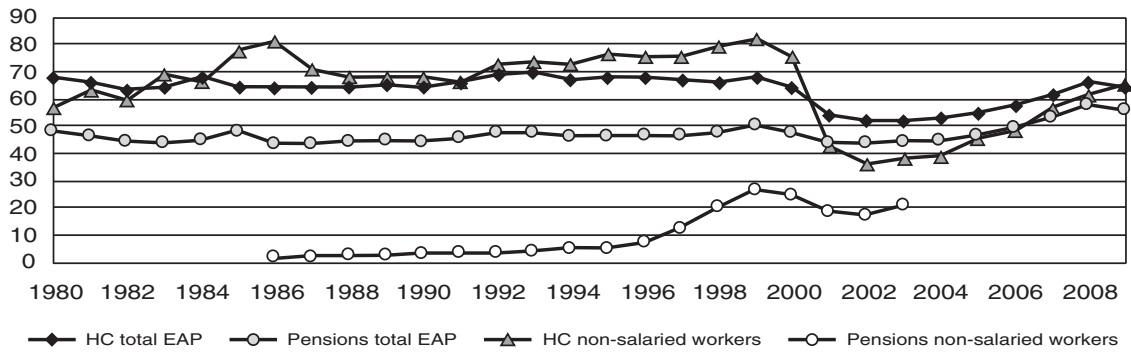

Figure 5 Costa Rica, coverage of social insurance, health care, and pensions, 1980-2009 (percentages). Data from Caja Costarricense del Seguro Social. In 2000 a new and centralized database improved national records for the insured population, which explains the apparent sudden drop in pensions as well as health-care coverage. 
make coverage virtually universal. All services, from primary to specialized care, are available to everyone, whether directly insured or family dependents.

By 1999, pension coverage reached half of the EAP, a level similar to $1980 .^{7}$ In 2006, 60 percent of all people age sixty-five and older received old-age transfers. It is noteworthy that the same occurred among the poor elderly, more than half of whom had pensions from social assistance programs and drew the remainder of their income from social insurance. Coverage among the self-employed has shown a particularly remarkable increase (reaching almost 50 percent) (see figure 5). This is all the more impressive considering that the relative importance of the self-employed had also increased considerably.

Costa Rica thus maintained one of the most active and generous welfare regimes in Latin America and did not introduce radical measures aimed at creating residual social policies, as did Argentina or Chile. Compared to the previous period, Costa Rican social policies actually increased their redistributive capacity, partly compensating increased inequality in the primary distribution of income. Household survey data show that between 1988 and 2004 the Gini coefficient of primary distribution deteriorated from 0.373 to 0.487 . Meanwhile, the destratifying effect of social policy increased so that the post-transfer coefficient was 0.311 in 1988 and 0.404 in 2004 (Trejos 2006).

\section{The Lack of Complementarities and Its Consequences}

The resilience of the universal welfare regime and the creation of more dynamic comparative advantages seem to point to the emergence of true complementarities between the production and welfare regimes and to a resolution of the problems of the previous era. The reality, however, is much more complex, and complementarities have failed in at least two ways. The growing segmentation of the labor market, together with the continuous dependence on payroll taxes, has created significant funding shortfalls. This has contributed to a drop in the quality of social services and a growing segmentation of the welfare regime. At the same time, the welfare regime has been unable to secure the level and type of skills that the economy requires, particularly in high-productivity sectors.

Although unemployment has not increased in Costa Rica over the long run, informal work has expanded to become the primary source of employment (between five and seven of every ten workers entering the labor force each year). As a result, in 2006 the informal sector accounted for 35 percent of the working population, compared to slightly more than 20 percent in the early 1980s. This is a result of fundamental changes in the production regime: peasants were displaced from traditional agriculture, while well-paid professional and managerial jobs were created. In 1994 the wealthiest 10 percent earned about twenty-five times more than the poorest 10 percent. However, by 2004 the gap had increased to thirty-five times (Villasuso 2008). Thus, the Costa Rican labor market is today much more segmented than ever before.

7. Current statistical records became more reliable (and less prone to overestimation) in 2001. 


\section{Latin American Research Review}

Growing informality has contributed to shrinking financial resources, which are still heavily dependent on payroll taxes (figure 6). Table 3 presents the evolution of average wages, average contributions, the relative weight of average contributions to total wages, and the annual variations. ${ }^{8}$ By 2010, contributions had just regained their 1985 value (10.85 percent and 10.07 percent, respectively) despite increased payroll tax rates. The downside is the simultaneous expansion of social benefits and the increased proportion of informal workers who do not contribute to social policies but do receive its benefits.

Funding shortfalls, particularly dramatic at the beginning of the 1980s but still persistent, resulted in a reduction of public servants, an increase of untenured personnel, and the growth of contracting out (Martínez Franzoni and Mesa-Lago 2003). Waiting lists also grew and contributed to mounting dissatisfaction with the system-although not to a reduction of general public support. Ironically, cutbacks were taking place at the same time that demands for new social services and rights were increasing (Vargas Cullell, cited in Seligson and Martínez Franzoni 2010). For instance, people demanding access to high cost HIV/AIDS-related medicines or patients facing terminal illness went to the Constitutional Court, won their cases, and had social insurance take care of their needs. ${ }^{9}$

The drop in the quality of public social services, coupled with a larger and more diversified supply of private services, has contributed to the growth of private risk management in health care as well as in education and pensions. Between 1991 and 2001, for example, public spending on health care showed a 5 percent annual increase, below the 8 percent average increase in private spending (Picado, Acuña, and Santacruz 2003). In only five years, between 1993 and 1998, the proportion of out-of-pocket total health-care spending increased by five times (Herrero and Durán 2001). In the past decade, the share of private spending among the population has systematically expanded, from 23.2 percent in 2000 to 32.6 percent in $2009 . .^{10}$

The growth of private provision has also taken place in other sectors, from private schools (including secondary schools) to individual pension funds. It has mostly (though not exclusively) been driven by middle- and upper-middleincome groups. For example, almost 60 percent of all private health-care spending in the early 2000s came from the wealthiest 25 percent of the population (Picado, Acuña, and Santacruz 2003).

The growing segmentation of the welfare system may contribute to political tensions as well. Social policies are primarily funded by workers who no longer use them, preferring the private sector instead. In the short run, this exit weakens cross-class distributional coalitions and therefore the quality of services, which in turn weakens cross-class coalitions even further (Martínez Franzoni and Voorend 2009). Spending has no doubt become more progressive than before, yet at the cost of losing previously attained degrees of social cohesion (Pérez Sáinz et al. 2004).

8. Average contributions to total wages consolidate workers and employers' contributions.

9. The Constitutional Court (Chamber IV) of the Supreme Court hears all matters related to constitutional rights, which has turned it into a key public policy maker (Vargas Cullell 2008).

10. See "Costa Rica," World Health Organization, http://www.who.int/nha/country/cri/en/. 


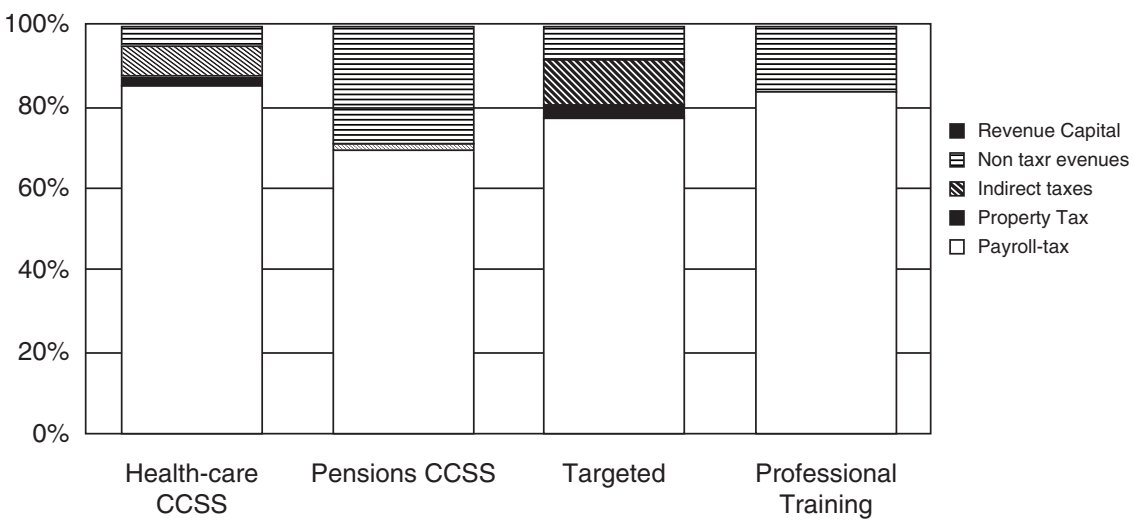

Figure 6 Social policy regime: Funding source by policy, 2004 (percentages). Data from Castro Méndez and Martínez Franzoni (2010). "Targeted" includes subsidies for pensions, housing, school incentives, rural sanitation, and nutrition and caretaking.

Table 3 Costa Rica: Wages and contributions to social policy among formal workers, 1985-2010, as monthly colones

\begin{tabular}{lcccr}
\hline Average & $\begin{array}{c}\text { Absolute average } \\
\text { contribution to } \\
\text { social policy }\end{array}$ & $\begin{array}{c}\text { Contribution as } \\
\text { percentage of } \\
\text { average wages }\end{array}$ & $\begin{array}{r}\text { Annual } \\
\text { variation }\end{array}$ \\
\hline 1985 & $197,117.9$ & $19,854.5$ & 10.07 & \\
1986 & $207,715.4$ & $21,295.9$ & 10.25 & 0.18 \\
1987 & $195,203.0$ & $16,247.4$ & 8.32 & -1.93 \\
1988 & $194,998.6$ & $15,956.4$ & 8.18 & -0.14 \\
1989 & $202,381.2$ & $16,951.7$ & 8.38 & 0.19 \\
1990 & $209,004.9$ & $17,467.4$ & 8.36 & -0.02 \\
1991 & $202,603.8$ & $17,315.3$ & 8.55 & 0.19 \\
1992 & $212,299.9$ & $18,018.9$ & 8.49 & -0.06 \\
1993 & $227,983.4$ & $19,732.2$ & 8.66 & 0.17 \\
1994 & $239,235.4$ & $21,238.0$ & 8.88 & 0.22 \\
1995 & $234,502.0$ & $21,113.0$ & 9.00 & 0.13 \\
1996 & $239,247.7$ & $21,484.2$ & 8.98 & -0.02 \\
1997 & $235,824.0$ & $21,002.3$ & 8.91 & -0.07 \\
1998 & $241,574.6$ & $21,778.7$ & 9.02 & 0.11 \\
1999 & $261,101.4$ & $23,850.5$ & 9.13 & 0.12 \\
2000 & $263,955.8$ & $24,031.4$ & 9.10 & -0.03 \\
2001 & $234,237.4$ & $21,568.8$ & 9.21 & 0.10 \\
2002 & $237,805.6$ & $22,520.7$ & 9.47 & 0.26 \\
2003 & $239,210.6$ & $22,963.6$ & 9.60 & 0.13 \\
2004 & $241,507.5$ & $23,359.6$ & 9.67 & 0.07 \\
2005 & $234,234.1$ & $22,714.0$ & 9.70 & 0.02 \\
2006 & $244,290.5$ & $23,833.1$ & 9.76 & 0.06 \\
2007 & $252,238.8$ & $24,729.9$ & 9.80 & 0.05 \\
2008 & $259,528.5$ & $26,417.3$ & 10.18 & 0.37 \\
Source: Central Bank. & & & & \\
\hline & & & &
\end{tabular}


In the medium run, this situation may lead to a potentially explosive political paradox. How long will middle- and upper-middle-income workers be willing to pay twice for services such as health care, once via payroll taxes and again via out-of-pocket spending?

The final shortcoming of the relation between the welfare and the production regimes has been the former's inability to provide the latter with adequate skills. The country moved from inadequately using its human capital to having training and education policies that fell behind a rapidly changing labor market. First, spending on secondary education decreased significantly in the 1980s. This led to a decade-long reduction in net enrollment rates along with very high and stillpersistent dropout rates: only four out of every ten youths entering high school complete their degrees.

Second, technical training has failed to meet market demands, particularly from the new leading sectors. Costa Rica is facing bottlenecks in specific areas, including information technology specialists, workers with English-language skills, and training institute instructors (Paus 2010). There is also a need to build tertiary curricula that respond with ever-greater flexibility to the needs of outsourcing TNCs and potential domestic suppliers. This targeted, selective education policy can simultaneously improve the quality of secondary education and upgrade skills among people with fewer years of formal education, but requires state capabilities and institutional coordination that Costa Rica may currently lack.

\section{Could Real Complementarities Emerge?}

We have shown how much the production regime has changed during the past three decades and how difficult it has been to secure better complementarities. A healthy funding of the welfare regime is harder than before: Costa Rica may not be spending enough in education or using resources properly. As a result, growing structural heterogeneity is contributing to a gradual move toward a segmented welfare regime-with the wealthy increasingly relying on the private system, and public services becoming less effective.

A good deal of the problem, however, has to do with the prevailing funding arrangements behind social policy. Dependence on payroll taxes to fund social insurance and social assistance, and to partially fund the training system, seems to have worked in the past, when formal employment was growing rapidly and global competition was less intense. However, payroll taxes are less likely to work in a more competitive environment with higher levels of heterogeneity and informality. Could Costa Rica modify these funding arrangements? Could it reduce dependence on payroll taxes and expand general tax revenues? Given that the economy has performed relatively well-with an average growth rate in GDP per capita of 2.0 percent between 1995 and 2008-an expansion of resources through these means is not out of the question.

The expansion of general taxes, however, has been difficult. Total taxes as a percentage of GDP have increased only from an average of 11.6 percent in the 1990s to 13.4 percent in the 2000s-less than two percentage points. Costa Rica's 
Table 4 Estimated tax losses as a result of the export-processing zone incentives, millions of current colones and percentage shares, 1997-2005

\begin{tabular}{|c|c|c|c|c|c|c|}
\hline Year & $\begin{array}{c}\text { Estimated } \\
\text { income tax } \\
\text { losses }\end{array}$ & $\begin{array}{l}\text { Total } \\
\text { revenues in } \\
\text { income taxes }\end{array}$ & $\begin{array}{c}\text { Income tax } \\
\text { losses } \\
(\% \text { total })\end{array}$ & $\begin{array}{l}\text { Estimated } \\
\text { total } \\
\text { tax loss }\end{array}$ & $\begin{array}{c}\text { Total } \\
\text { tax } \\
\text { revenues }\end{array}$ & $\begin{array}{c}\text { Total tax } \\
\text { losses } \\
(\% \text { total) }\end{array}$ \\
\hline 1997 & $5,427.45$ & $55,924.30$ & 9.7 & $22,141.75$ & $363,540.30$ & 6.09 \\
\hline 1998 & $22,373.18$ & $77,001.10$ & 29.1 & $44,903.64$ & $444,484.80$ & 10.10 \\
\hline 1999 & $10,088.93$ & $118,859.10$ & 8.5 & $37,522.10$ & $547,434.40$ & 6.85 \\
\hline 2000 & $15,651.87$ & $122,031.70$ & 12.8 & $34,951.40$ & $599,100.50$ & 5.83 \\
\hline 2001 & $22,416.32$ & $152,653.50$ & 14.7 & $50,786.66$ & $704,130.30$ & 7.21 \\
\hline 2002 & $32,200.13$ & $169,879.50$ & 19.0 & $62,924.78$ & $781,798.00$ & 8.05 \\
\hline 2003 & $53,432.37$ & $217,494.00$ & 24.6 & $79,297.25$ & $925,481.70$ & 8.57 \\
\hline 2004 & $54,506.19$ & $254,438.20$ & 21.4 & $89,125.48$ & $1,079,610.80$ & 8.26 \\
\hline 2005 & $96,226.20$ & $312,169.40$ & 30.8 & $126,563.38$ & $1,290,285.80$ & 9.81 \\
\hline
\end{tabular}

tax burden remains low in comparative perspective and below that required to fund urgent improvements in infrastructure and other areas (Agosín, Machado, and Schneider 2009).

There are at least two reasons the country has been unable to raise revenue levels. First, the nature of Costa Rica's new production regime contributes to low tax revenues because the most dynamic sectors pay minimal taxes. The tourist sector, nontraditional agriculture exports, and the export-processing zones have benefited from significant tax incentives. Companies in the export-processing zones, for example, have paid payroll taxes but not corporate taxes or import tariffs. Table 4 estimates the public revenue losses from these incentives. ${ }^{11}$ In 2005, revenues from the income tax could have been significantly higher if companies within the export-processing zones had paid corporate taxes. The elimination of all tax subsidies for the sector could increase Costa Rica's total tax burden by 5-10 percent per year.

Second, most attempts to expand progressive taxation have failed. Starting in 2002, a comprehensive tax reform aimed to expand the tax burden as a percentage of GDP by at least two percentage points was discussed in the Legislative Assembly for more than three years but failed to pass. It included broadening the tax base of the value-added tax as well as the introduction of a global income to calculate the personal income tax. The reform aimed to fund some social programs and to secure the sustainability of public debt. The proposal met with opposition coming from the business elite and social movements, which understood the need for higher taxes but did not want to pay those taxes themselves. Recent and ongoing efforts to expand general taxes have advanced very slowly; it has been easier for the government to continue using high payroll taxes as a prominent funding

11. This static exercise assumes that firms would not change their performance if taxes were increased (Ernst and Sánchez-Ancochea 2008). 
source for social policy. Payroll taxes in fact increased from 30.75 percent prior to 1980 to 34.75 percent as recently as 2000 , to fund new components of the welfare regime, particularly individual labor funds and pension funds for salaried workers. The most recent increase took place in 2005, when employers, workers, and the government agreed to gradually increase their contributions to the collective pension fund (CCSS) over a period of several decades. Such agreement took place in the context of negotiations among labor, business, and government authorities around a broader agenda explicitly aimed at strengthening social security. ${ }^{12}$ The main business organization (Unión Costarricense de Cámaras y Asociaciones del Sector Empresarial Privado) has never challenged the importance of social security for social peace, nor has it demanded that payroll taxes be cut. We are not aware of studies that explain why this is the case, but factors seem to range from a rapidly expanding financial sector more interested in administering rather than downsizing social security to the fact that social security is still deeply seated in the notion of Costa Rican uniqueness and its national identity.

\section{IMPLICATIONS}

In this article we have drawn from the Costa Rican showcase of human development and universalistic social policies to address how the production regime supports and constrains the welfare regime. We have shown that there were some positive relations between the two regimes at various points (e.g., relatively effective funding between 1950 and 1980, public investment in job creation, some upgrading of comparative advantages since the 1980s) but that these were never either fully or mostly complementary.

At the heart of our interpretation of Costa Rica's performance-and Latin America's pervasive lack of complementarities-lies the dominance of structural heterogeneity in the production regime. The existence of very different sectors in the economy (which, with the danger of oversimplification, we have called leading sectors and low-productivity sectors) constitute a significant obstacle for the consolidation of complementarities. During the period 1950-1980, Costa Rica succeeded in promoting low-productivity sectors, thus expanding formal employment and consolidating a stable funding mechanism for the welfare state. Nevertheless, it failed to change the leading sectors so that they could draw from the skills created by the welfare regime. More recently, the relationship between the leading sector and the welfare state has improved, but the low-productivity sector has been left behind and economic segmentation has accelerated.

The analysis presented in this article has significant implications for Costa Rica's prospects but, more generally, for current theoretical and policy debates. In the specific case of Costa Rica, we have shown that the country has made some progress but that both the production and welfare regimes are increasingly segmented. If the country is to sustain universal policies over the long run, it may need to modify its tax system (moving from payroll taxes to general taxes) and

12. For a characterization of the process, see Martínez Franzoni (2008b). 
reduce structural heterogeneity and thus informality-all difficult tasks under current global conditions.

In terms of theory, our article highlights changing tensions between the production and welfare regimes in peripheral countries-and potentially in developed nations. Even in successful societies like Costa Rica-or Mauritius and Kerala, India, two other cases of social democracy in Sandbrook and colleagues' (2007) book - the production regime has faced enormous difficulties in upgrading and supporting universal social policies, but the nature of such difficulties change over time. Under the current globalized economy, national borders have liberalized, incentives have revolved around leading sectors, and structural heterogeneity has intensified. Raising taxes and securing political support for universalism under these conditions may be increasingly difficult. In the handful of countries that have managed to establish a universal welfare regime, the segmentation of the production regime can thus easily give rise to the segmentation of previously universal social policies.

Although the tensions between production and welfare regimes are particularly evident in the periphery, they may also be appearing in a growing number of developed countries. France and Germany, for example, are witnessing a growing duality in their production structure and labor market: well-paid, full-time jobs concentrate on core manufacturing jobs, and low-wage, part-time employment is expanding in other parts of the economy (Palier and Thelen 2010). A more dual production regime is also resulting in more segmented welfare provision and, as a result, in greater inequality-in what we can call a slow Latin Americanization of Europe. To be sure, this problem is particularly dramatic in countries dependent on social insurance and payroll taxes, but tensions between production and welfare are also emerging in the Nordic countries (Kangas and Palme 2005; Pontusson 2005).

In terms of policy implications, our article offers some lessons about Latin America's future. Some countries in the region are slowly moving toward the creation or re-creation of universal social programs together with the expansion of social assistance and education (López-Calva and Lustig 2010). Cornia (2010, 85) talks about a new "policy model of fiscally prudent social democracy," with Latin American countries succeeding for the first time in welfare services spending within a global, open environment. Unfortunately, these changes have taken place in the context of relatively unchanged productive regimes that remain specialized in primary resources and present high levels of structural heterogeneity (Economic Commission for Latin America and the Caribbean 2010). Costa Rica shows that a generous welfare regime and a relatively traditional production regime may coexist for some time, but the combination is likely to eventually generate significant tensions. At the end, universalistic social systems can be maintained and can lead to improvements in income distribution only if they are accompanied by successful production regimes that provide the required funding (ideally through general taxes), formal jobs, and demand for skills. This is undoubtedly a difficult objective in the current global era, but a fundamental one nevertheless. 


\section{REFERENCES}

Agosín, Manuel, Roberto Machado, and Aaron Schneider

2009 "The Struggle for Tax Reform in Central America." In The Political Economy of the Budget in the Americas, edited by Diego Sánchez-Ancochea and Iwan Morgan, 147-163. London: Institute for the Study of the Americas.

Blomström, Magnus, and Patricio Meller, eds.

1991 Diverging Paths: Scandinavian and Latin American Economic Development. Washington, DC: Inter-American Development Bank.

Brenes, Lidieth

1990 La nacionalización bancaria en Costa Rica: Un juicio histórico. San José: Facultad Latinoamericana de Ciencias Sociales.

Castro, Carlos

1995 "Estado y sectores medios en Costa Rica: Redimensionamiento de un pacto social." Cuaderno de Ciencias Sociales No. 81, Facultad Latinoamericana de Ciencias Sociales, San José.

Castro Méndez, Mauricio, and Juliana Martínez Franzoni

2010 "Un modelo exitoso en la encrucijada: Límites del desencuentro entre régimen laboral y de bienestar en Costa Rica." Revista Centroamericana de Ciencias Sociales 7 (1): 70-122.

Coates, David, ed.

2005 Varieties of Capitalism, Varieties of Approaches. London: Palgrave Macmillan.

Cornia, Andrea

2010 "Income Distribution under Latin America's New Left Governments." Journal of Human Development and Capabilities 11 (1): 85-114.

Crouch, Colin, Wolfgang Streeck, Robert Boyer, Bruno Amable, Peter A. Hall, and Gregory

Jackson

2005 "Dialogue on 'Institutional Complementarity and Political Economy."' SocioEconomic Review 3:359-382.

Economic Commission for Latin America and the Caribbean

2010 "Structural Heterogeneity and Productivity Gaps: From Fragmentation to Convergence." In Time for Equality: Closing Gaps, Opening Trails, 85-121. Santiago, Chile: Economic Commission for Latin America and the Caribbean.

Ernst, Christoph, and Diego Sánchez-Ancochea

2008 "Offshoring and Employment in the Developing World: The Case of Costa Rica." Employment Working Paper No. 4, Employment Analysis Unit, International Labor Organization, Geneva.

Esping-Andersen, Gøsta

1990 The Three Worlds of Welfare Capitalism. Princeton, NJ: Princeton University Press.

1996 "After the Golden Age? Welfare State Dilemmas in a Global Economy." In Welfare States in Transition: National Adaptations in Global Economies, edited by Gøsta EspingAndersen, 1-31. London: Sage Publications.

Estévez-Abe, Margarita, Torben Iversen, and David Soskice

2001 "Social Protection and the Formation of Skills: A Reinterpretation of the Welfare State." In Varieties of Capitalism: The Institutional Foundations of Comparative Advantage, edited by Peter A. Hall and David Soskice, 145-183. Oxford: Oxford University Press.

Filgueira, Fernando

1998 "El nuevo modelo de prestaciones sociales en América Latina: Residualismo y ciudadanía estratificada." In Ciudadanía y política social, edited by Brian Roberts, 71-116. San José: Facultad Latinoamericana de Ciencias Sociales and Social Science Research Council.

Garnier, Leonardo, and Laura Blanco

2010 Costa Rica: Un país subdesarrollado casi exitoso. San José: Uruk Editores.

Güendell, Ludwig

1988 "La política social y la asignación familiar en Costa Rica: 1973-1976." Cuadernos de Investigación No. 39, August, Consejo Superior Universitario Centroamericano, San José. 
Haggard, Stephan, and Robert R. Kaufman

2008 Development, Democracy, and Welfare States: Latin America, East Asia, and Eastern Europe. Princeton, NJ: Princeton University Press.

Hall, Peter A., and David Soskice

2001 "An Introduction to Varieties of Capitalism." In Varieties of Capitalism: The Institutional Foundations of Comparative Advantage, edited by Peter Hall and David Soskice, 1-69. Oxford: Oxford University Press.

Herrero, Fernando, and Fabio Durán

2001 El sector privado en el sistema de salud de Costa Rica. Financiamiento del Desarrollo 109, Comisión Económica para América Latina y el Caribe, Santiago, Chile. http:// www.eclac.cl/publicaciones/xml/5/7095/lcl1527e.pdf.

Huber, Evelyne, ed.

2001 Models of Capitalism: Lessons for Latin America. University Park: Pennsylvania State University Press.

Huber, Evelyne, and John D. Stephens

2001 Development and Crisis of the Welfare State: Parties and Policies in Global Markets. Chicago: University of Chicago Press.

Kangas, Olli, and Joakim Palme

2005 "Social Policy and Economic Development in the Nordic Countries: An Introduction." In Social Policy and Economic Development in the Nordic Countries, edited by Olli Kangas and Joakim Palme, 1-17. London: Palgrave Macmillan.

Kokko, Ari

2010 “The Swedish Model." UNU-WIDER Working Paper 2010/88, World Institute for Development Economics Research, United Nations University, Helsinki.

Korzeniewicz, Roberto Patricio, and William C. Smith

2000 "Poverty, Inequality, and Growth in Latin America: Searching for the High Road to Globalization." Latin American Research Review 35 (3): 7-54.

López-Calva, Luis F., and Nora Lustig, eds.

2010 Declining Inequality in Latin America: A Decade of Progress? Washington, DC: Brookings Institution Press.

Mares, Isabela, and Matthew E. Carnes

2009 "Social Policy in Developing Countries." Annual Review of Political Science 12: 93-113.

Martínez Franzoni, Juliana

2008a "Costa Rican Social Protection: The Accomplishments and Strains of a Showcase." Paper prepared under the UNRISD Project on Poverty Reduction and Public Policy Regimes, Geneva.

2008b “Costa Rica's Pension Reform: A Decade of Negotiated Incremental Change." In Lessons from Pension Reform in the Americas, edited by Stephen J. Kay and Tapen Sinha, 317-339. New York: Oxford University Press.

2008c "Welfare Regimes in Latin America: Capturing Constellations of Markets, Families and Policies." Latin American Politics and Society 50 (2): 67-100.

Martínez Franzoni, Juliana, and Carmelo Mesa-Lago

2003 Las reformas inconclusas: Pensiones y salud en Costa Rica: Avances, problemas y recomendaciones. San José: Fundación Ebert.

Martínez Franzoni, Juliana, and Diego Sánchez-Ancochea

2012 "The Road to Universal Social Protection: How Costa Rica Informs Theory", (with support from Héctor Solano). Working Paper 383, Kellogg Institute for International Research.

Martínez Franzoni, Juliana, and Koen Voorend

2009 "The Role of Distributional Coalitions in Welfare Regimes: Chile, Costa Rica and El Salvador." Social Policy and Administration 43 (4): 364-381.

Meléndez, Carlos

1998 Desde hace 50 años el día comienza con Dos Pinos: Historia de la Cooperativa de Productores de Leche R.L. San José: Asesorías Organizacionales.

Ministerio de Planificación Nacional y Política Económica

1998 Gobernando en tiempos de cambio: La Administración Figueres Olsen. San José: Ministerio de Planificación Nacional y Política Económica. 


\section{Latin American Research Review}

Montiel, Nancy

2001 "Rol del FODESAF en la superación de la pobreza en Costa Rica." Final Investigation Report, Instituto de Investigaciones en Ciencias Económicas, Universidad de Costa Rica, San José.

Palier, Bruno, and Kathleen Thelen

2010 "Institutionalizing Dualism: Complementarities and Change in France and Germany." Politics and Society 38 (1): 119-148.

Paus, Eva

2005 Foreign Investment, Development and Globalization: Can Costa Rica Become Ireland? London: Palgrave Macmillan.

2010 "The Uneven Development of Local Technological Capabilities in Costa Rica." Report for the International Labor Organization, Geneva.

Pérez Sáinz, Juan Pablo, Katharine Andrade-Eekhoo, Santiago Bastos, and Michael

Herradora

2004 La estructura social ante la globalización: Procesos de reordenamiento social en Centroamérica durante la década de los 90. San José: Facultad Latinoamericana de Ciencias Sociales and Comisión Económica para América Latina y el Caribe.

Perraton, Jonathan, and Ben Clift, eds.

2004 Where Are National Capitalisms Now? London: Palgrave Macmillan.

Picado, Gustavo, Edwin Acuña, and Javier Santacruz

2003 Gasto y financiamiento de la salud en Costa Rica: Situación actual, tendencias y retos. San José: Ministry of Health, Organización Panamericana de la Salud.

Pontusson, Jonas

2005 "Varieties and Commonalities of Capitalism." In Varieties of Capitalism, Varieties of Approaches, edited by David Coates, 163-188. New York: Palgrave Macmillan.

2011 "Once Again a Model: Nordic Social Democracy in a Globalized World." In What's Left of the Left: Democrats and Social Democrats in Challenging Times, edited by James Cronin, George Ross, and James Shoch, 89-116. Durham, NC: Duke University Press.

Reding, Andrew

1986 "Costa Rica: Democratic Model in Jeopardy." World Policy Journal 3 (2): 301-315.

Rosenberg, Mark

1983 Las luchas por el seguro social en Costa Rica. San José: Editorial Costa Rica.

Rovira, Jorge

1987 Costa Rica en los años '80. San José: Instituto Centroamericano de Documentación e Investigación Social (ICADIS), CRIES, and Editorial Porvenir.

2000 Estado y política económica en Costa Rica, 1948-1970. San José: Editorial de la Universidad de Costa Rica.

Sánchez-Ancochea, Diego

2004 "Leading Coalitions and Patterns of Accumulation and Distribution in Small Countries: A Comparative Study of Costa Rica and the Dominican Republic under Globalization." PhD diss., New School for Social Research, New York.

Sandbrook, Richard, Marc Edelman, Patrick Heller, and Judith Teichman

2007 Social Democracy in the Global Periphery: Origins, Challenges, Prospects. Cambridge: Cambridge University Press.

Schneider, Ben Ross

2009 "Hierarchical Market Economies and Varieties of Capitalism in Latin America." Journal of Latin American Studies 41 (3): 553-575.

Schneider, Ben Ross, and David Soskice

2009 "Inequality in Developed Countries and Latin America: Coordinated, Liberal and Hierarchical Systems." Economy and Society 38 (1): 17-52.

Segura-Ubiergo, Alex

2009 The Political Economy of the Welfare State in Latin America. Cambridge: Cambridge University Press.

Seligson, Mitchell A., and Juliana Martínez Franzoni

2010 "Limits to Costa Rican Heterodoxy: What Has Changed in 'Paradise'?" In Democratic Governance in Latin America, edited by Scott Mainwaring and Timothy Scully, 307-337. Stanford, CA: Stanford University Press. 
Trejos, Juan Diego

2006 "¿A quién beneficia el gasto público social en Costa Rica?" Paper presented at the Vargas, José 4th Annual Conference of the Central America Academy, San José, December.

1998 "Costa Rica en cifras." Revista de Ciencias Económicas 18 (1): 205-233.

Vargas Cullel, Jorge

2008 "Institucionalidad pública y redistribución social en Costa Rica." Paper prepared for the project on Public Policy Regimes and Reduction of Poverty, UN Research Institute for Social Development, Geneva.

Villasuso, Juan Manuel

2008 "Medio siglo de economía política y política económica en Costa Rica." Paper prepared for the project on Public Policy Regimes and Reduction of Poverty, UN Research Institute for Social Development, Geneva. 
